\title{
Effect of Zinc Nutrition in Mitigating Late Sowing Induced Heat Stress in Wheat Crop
}

\author{
Dheeraj Chatti* and Atul Kumar
}

Department of Plant Physiology, GBPUAT, Pantnagar, U. S. Nagar (dist.), Uttarakhand, India

*Corresponding author

\begin{tabular}{l} 
K e y w or d s \\
$\begin{array}{l}\text { Zinc, heat stress, } \\
\text { yield, grain weight }\end{array}$ \\
Article Info \\
$\begin{array}{l}\text { Accepted: } \\
\text { 22 December } 2019 \\
\text { Available Online: } \\
\text { 20 January 2020 }\end{array}$ \\
\hline
\end{tabular}

Keywords

Zinc, heat stress, 20 January 2020

\section{A B S T R A C T}

Intending to scrutinise the effect of zinc nutrition in mitigating heat stress in late sown wheat crop, an experiment was conducted at Norman E. Borlaug crop research centre and Department of Plant Physiology, CBSH, G. B. Pant University of Agriculture and Technology, Pantnagar, Uttarakhand. Effect of three different $\mathrm{Zn}$ treatments i.e soil $\mathrm{ZnSO}_{4}$ treatment (T1), foliar $\mathrm{ZnSO}_{4}$ spray (T2) and soil $\mathrm{ZnSO}_{4}$ treatment+foliar $\mathrm{ZnSO}_{4}$ spray (T3) were studied on three varieties of wheat varieties i.e, UP 2425 (V1), UP 2565 (V2) and HD 3059 (V3) sown at late sown conditions i.e on the dates 2412-2017 and 24-12-2018 during first (2017) and second (2018) seasons respectively to expose wheat crop to late sowing induced heat stress. Effect of $\mathrm{Zn}$ treatments on growth and yield parameters like plant height, number of leaves, panicle length and 1000 grains weight were evaluated under $\mathrm{Zn}$ treatments. Although $\mathrm{Zn}$ treatments showed no significant effect on growth parameters, a significant per cent improvement of 9.08 and 14.94 was observed for thousand grain weight under $\mathrm{Zn}$ treatments over control.

\section{Introduction}

Wheat is dominant staple food crop of the world including India. Globally wheat stands second in terms of total production with a quantum of $647 \mathrm{Mt}$ (FAOSTAT, 2012). According to Braun et al., (2010) wheat crop supplies around $20 \%$ dietary energy of man across the planet earth. India has the largest area under wheat (31.2 Mha), with a production of $95.9 \mathrm{Mt}$ and productivity of $3.08 \mathrm{t} / \mathrm{ha}$ (DES, 2014). Wheat is basically a long day crop primarily grown in temperate region and also at higher altitudes under tropical regions in winter season. It requires relatively low temperature to accomplish satisfactory growth and development. Rice cultivation during kharif has delayed wheat 
sowing beyond the optimum of midNovember resulting heat stress especially during grain growth and development stage. Similarly high temperature stress is also faced by wheat crop in cotton-wheat system.

Both the proximity to the equator and the popular cropping systems, which involve late sowing of wheat, are the major reasons of wheat exposing to high temperatures during grain filling stage in India and other neighbouring countries. This increase in temperature at the time of grain growth stage is referred as terminal heat stress. The shrinkage of cool period for the wheat crop and the incremental threat of terminal heat stress make the wheat crop vulnerable to heat stress (Sharma et al., 2008).

Experiments conducted under both field and stimulated conditions reveal that an increase of $1{ }^{\circ} \mathrm{C}$ temperature resulted in a yield reduction of 570 and $620 \mathrm{~kg} / \mathrm{ha}$ from maximum yield in spring and winter wheat cultivars, respectively (White and Reynolds, 2001). Climate change-induced increase in temperature is probable to reduce wheat production in developing countries (where around $66 \%$ of all wheat is produced) by 20 $30 \%$.

The twin stresses of Zinc deficiency and delayed sowing induced high temperature stress often occur in combination throughout many of the global cropping areas and the possible interaction between two stress factors is highly important. Zinc plays a key role in the maintenance of photosynthetic activity, the preservation of membrane integrity and the continuance of enzyme activity, as well as an important factor in plant's defence against reactive oxygen species, which proliferate under various stress conditions, including heat stress. While $\mathrm{Zn}$ also plays a key role in maintaining membrane integrity, this suggests a possible link between zinc deficiency and susceptibility to heat stress. The present investigation has been confined primarily to the response of late sown wheat to $\mathrm{Zn}$ nutrition. The main aim of this study was to determine if elevated supplies of $\mathrm{Zn}$ could maintain photosynthetic activity and grain yield in wheat plants under delayed sowing.

\section{Materials and Methods}

This experiment was conducted at Norman E. Borlaug crop research centre and Department of Plant Physiology, CBSH, G. B. Pant University of Agriculture and Technology, Pantnagar, Uttarakhand. Three varieties of wheat i.e, UP 2425 (V1), UP 2565 (V2) and HD 3059 (V3) were sown at late sown conditions i.e on the dates 24-12-2017 and 24-12-2018 during first and second seasons respectively to expose wheat crop to late sowing induced heat stress.

Three different zinc treatments were applied i.e soil $\mathrm{ZnSO}_{4}$ treatment (T1), foliar $\mathrm{ZnSO}_{4}$ spray (T2) and soil $\mathrm{ZnSO}_{4}$ treatment+foliar $\mathrm{ZnSO}_{4}$ spray (T3). Control treatment (T4) was maintained without any $\mathrm{ZnSO} 4$ supply. Treatments were given during tillering, panicle emergence and grain filling stages and observations were collected during panicle emergence, grain filling and harvesting stages.

\section{Number of leaves}

Number of leaves from each treatment was recorded manually and average panicle length value was calculated.

\section{Plant height (cm)}

Plant height from 3 plants was measured manually in all the treatment plots by using meter scale before harvesting the crop and average plant weight was calculated. 


\section{Panicle length $(\mathrm{cm})$}

Length of 3 panicles from each treatment was recorded manually with meter scale and average panicle length value was calculated.

\section{Thousand grain weight $(\mathrm{g})$}

Thousand seeds from the samples of each treatment were counted and their average weight was recorded.
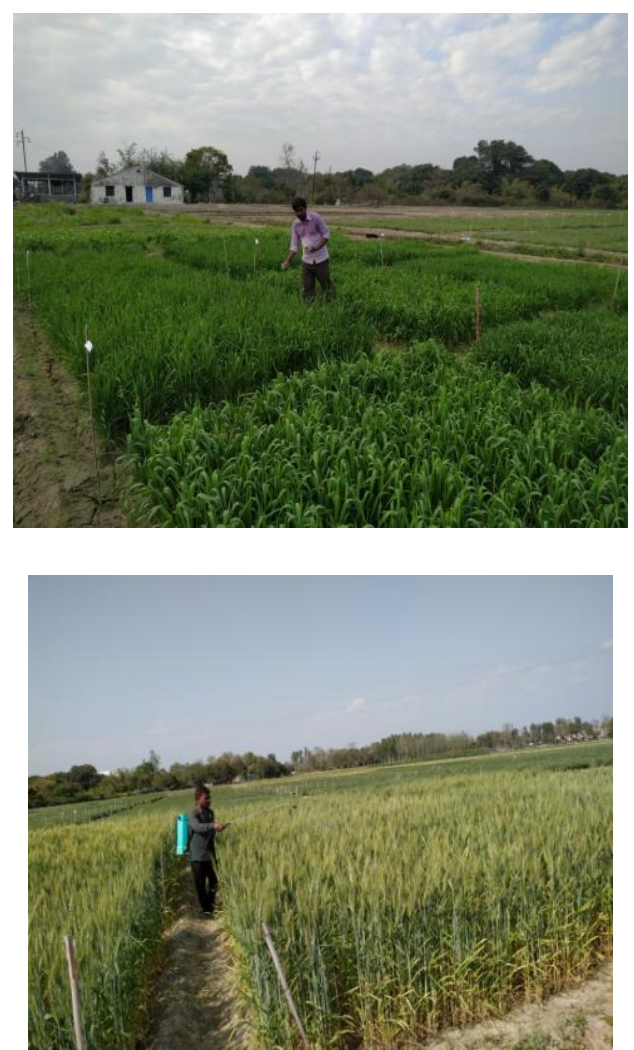

Figure.1 \&2 Soil and foliar application of $\mathrm{ZnSo}_{4}$ in late sown wheat crop

\section{Results and Discussion}

\section{Number of leaves}

Zinc nutrition showed no significant variation in number of leaves. In the first season, number of leaves increased under T3 (13.11) followed by T2 (13.11) and decreased under T1 (12.88) compared to control (13.00). In the second season under $\mathrm{T} 1 \quad(13.22)$ and $\mathrm{T} 2$ (13.22) number of leaves increased and decreased under T3 (12.88) over control (13.00). Highest number of leaves was noted for V3 (13.41) and V2 (13.25) in season 1 and season 2 respectively. (Table. 1). These results are in disagreement with Keram et al., (2014) who observed increase in number of plant leaves in wheat with $\mathrm{Zn}$ nutrition due to its role the faster cell division and cell elongation within the plant. Zinc acts as a functional, structural or regulatory co-factor and is involved in many enzymatic activities and synthesis of tryptophan and production of growth hormones such as Indole acetic acid..

\section{Plant height (cm)}

Effect of zinc on the mean values of plant height in late sown wheat crop is presented in table no 2. During the first season, significantly higher plant height was recorded for wheat plants with foliar $\mathrm{Zn}$ treatment (94.44) compared to control (93.00). Plants with soil + foliar $\mathrm{Zn}$ treatment showed significantly lower plant height (92.22) and almost no difference was noted for plants with soil $\mathrm{Zn}$ treatment (93.22) compared to control. Among all varieties, UP 2565 noted highest plant height (94.00).

In the second season, No variation in plant height was observed in plants under $\mathrm{T} 1$ (92.88) compared to control (92.88) whereas non significant increase and decrease in plant height was observed under T2 (93.88) and T3 (92.00) respectively over the control. Variety UP2565 was the tallest among all the varieties (94.00). (Table.2)

Due to late planting heat stress, the development of plant organs, photosynthesis rate and transfer of assimilate from source (Hasan, 2009) were remarkably affected, which was reflected by overall shortening of wheat plant height, whereas Sajid ali et al., (2016) reported that heat stress imposed at pre-anthesis stage had minimum effect on plant height in wheat. 
In the present investigation, zinc treatments did not seem to significantly influence plant height in late sown wheat crop. In the first season, a slight increment of $1.54 \%$ was recorded under $\mathrm{T} 2$, whereas almost no change was noted under $\mathrm{T} 1$ and $\mathrm{T} 3$. In the second season, marginal increment and decrement of $1.07 \%$ and $0.94 \%$ was recorded under $\mathrm{T} 2$ and T3 respectively over the control. The present finding are in disagreement with Mehandi et al., (2012) and Maurya et al., (2010), who observed that increased rates of photosynthesis and chlorophyll formation due to the zinc, accelerated the meristem activity of plant that led to progressive increase in internode length where as in conformity with findings of Zozi et al., 2012 where foliar zinc application did not affect the plant height in wheat crop.

\section{Panicle length (cm)}

Effect of $\mathrm{Zn}$ nutrition on panicle length is presented in table no. 10, The mean values for panicle length were $11.11,10.94,11.44$ and 11.00 under T1, T2, T3 and T4 respectively during the first season. In the second season, mean values for panicle length were noted as 11.50, 11.00, 10.83 and 11.00 under T1, T2, T3 and T4 respectively. Variety UP2425 (11.25) and UP2565 (11.37) obtained highest panicle length among all the varieties during both the seasons.

Zinc treatments showed no significant influence on panicle length in the present experiment on late sown wheat crop during both the seasons although a marginal nonsignificant increment of $4 \%$ under T3 and $4.54 \%$ under $\mathrm{T} 1$ were observed during season 1 and season 2 respectively. These findings are in disagreement with abbas et al., (2009) and Shaheen et al., (2009) who reported that $\mathrm{Zn}$ increased spike length wheat through improved catalytic activity.

\section{Thousand grain weight (g)}

Mean values for 1000 grain weight were presented in table no. 9, All the treatments with $\mathrm{Zn}$ nutrition increased 1000 grain weight over control. During the first season, highest 1000 grain weight was recorded under T2 (38.10) followed by T3 (36.33) and T1 (33.33). During the second season, highest 1000 grain weight was recorded under T3 (37.91) followed by $\mathrm{T} 1$ (33.66) and $\mathrm{T} 2$ (37.49). Variety UP2425 $(34.95,36.47)$ noted greater 1000 grain weight among all the varieties during both the seasons.

Heat stress can significantly impair photosynthesis reducing the amount of assimilates available to the grain (Sharkey, 2005). High temperature during grain filling causes a significant reduction in the duration of grain filling and adversely affect the grain weight. (Wardlaw et al., 2002).

In the current study, $\mathrm{Zn}$ nutrition seems to ameliorate negative effects of late sown heat stress by improving 1000 grain weight under all the $\mathrm{Zn}$ treatments. A significant escalation by $9.08 \%$ and $14.94 \%$ was recorded under T3 compared to control in both the seasons respectively.

This response can be related to key role of zinc in biosynthesis of IAA, regulating the auxin concentration in plant and other biochemical, physiological activates like photosynthesis, respiration, nitrogen metabolism and initiation of primordia for reproductive parts facilitating better translocation of desired metabolites to the yield contributing parts of plant like seeds and leads to increase in seed weight. These results are in agreement with Firdous et al., (2018) and Moghadam et al., (2012). 
Table.1 Effect of zinc on number of leaves in late sown wheat crop $(\mathrm{cm})$

\begin{tabular}{|c|c|c|c|c|c|c|c|c|}
\hline \multicolumn{5}{|c|}{2017} & \multicolumn{4}{|c|}{2018} \\
\hline & V1 & V2 & V3 & Mean T & V1 & $\mathbf{V 2}$ & V3 & Mean T \\
\hline T4 & 13.33 & 12.00 & 13.66 & 13.00 & 13.33 & 12.66 & 13.00 & 13.00 \\
\hline $\mathbf{T 1}$ & 13.00 & 12.66 & 13.00 & 12.88 & 12.66 & 13.00 & 14.00 & 13.22 \\
\hline $\mathbf{T} 2$ & 12.00 & 14.33 & 13.00 & 13.11 & 12.66 & 14.33 & 12.66 & 13.22 \\
\hline T3 & 13.00 & 12.66 & 14.00 & 13.22 & 12.66 & 13.00 & 13.00 & 12.88 \\
\hline \multirow[t]{2}{*}{ Mean V } & 12.83 & 12.91 & 13.41 & & 12.83 & 13.25 & 13.16 & \\
\hline & \multicolumn{2}{|c|}{ TREATMENT } & IETY & TXV & \multicolumn{2}{|c|}{ TREATMENT } & VARIETY & TXV \\
\hline $\operatorname{SEm} \pm$ & \multicolumn{2}{|c|}{0.13} & 21 & 0.36 & \multicolumn{2}{|c|}{0.25} & 0.23 & 0.40 \\
\hline CD $(5 \%)$ & \multicolumn{2}{|c|}{0.45} & 63 & 0.27 & \multicolumn{2}{|c|}{0.88} & 0.70 & 1.41 \\
\hline
\end{tabular}

Table.2 Effect of zinc on plant height in late sown wheat crop $(\mathrm{cm})$

\begin{tabular}{|c|c|c|c|c|c|c|c|c|}
\hline \multicolumn{5}{|c|}{2017} & \multicolumn{4}{|c|}{2018} \\
\hline & V1 & V2 & V3 & Mean T & $\mathbf{T 1}$ & $\mathbf{T 2}$ & T3 & Mean T \\
\hline T4 & 92.33 & 95.66 & 91.00 & 93.00 & 92.00 & 95.33 & 91.33 & 92.88 \\
\hline T1 & 94.00 & 93.00 & 92.66 & 93.22 & 93.00 & 93.00 & 92.66 & 92.88 \\
\hline $\mathbf{T 2}$ & 96.00 & 95.33 & 92.00 & 94.44 & 95.66 & 95.33 & 90.66 & 93.88 \\
\hline T3 & 92.66 & 92.00 & 92.00 & 92.22 & 91.66 & 92.33 & 92.00 & 92.00 \\
\hline \multirow[t]{2}{*}{ Mean V } & 93.75 & 94.00 & 91.91 & & 93.08 & 94.00 & 91.66 & \\
\hline & \multicolumn{2}{|c|}{ TREATMENT } & RIETY & TXV & \multicolumn{2}{|c|}{ TREATMENT } & VARIETY & TXV \\
\hline SEm \pm & \multicolumn{2}{|c|}{0.28} & .56 & 0.97 & \multicolumn{2}{|c|}{0.38} & 0.59 & 1.03 \\
\hline CD $(5 \%)$ & \multicolumn{2}{|c|}{0.99} & 68 & 3.37 & \multicolumn{2}{|c|}{1.34} & 1.78 & 3.56 \\
\hline
\end{tabular}

Table.3 Effect of zinc on panicle length in late sown wheat crop $(\mathrm{cm})$

\begin{tabular}{|c|c|c|c|c|c|c|c|c|}
\hline & \multicolumn{9}{|c|}{$\mathbf{2 0 1 7}$} & \multicolumn{4}{c|}{$\mathbf{2 0 1 8}$} \\
\hline T1 & 11.167 & 10.667 & 11.500 & 11.111 & 11.333 & 11.167 & 12.000 & 11.500 \\
\hline T2 & 11.000 & 11.333 & 10.500 & 10.944 & 10.667 & 11.333 & 11.000 & 11.000 \\
\hline T3 & 11.167 & 11.167 & 12.000 & 11.444 & 10.333 & 11.833 & 10.333 & 10.833 \\
\hline T4 & 11.667 & 11.333 & 10.000 & 11.000 & 10.500 & 11.167 & 11.333 & 11.000 \\
\hline Mean V & 11.250 & 11.125 & 11.000 & & 10.708 & 11.375 & 11.167 & V3 \\
\hline
\end{tabular}


Table.4 Effect of zinc on 1000 grain weight in late sown wheat crop (g)

\begin{tabular}{|c|c|c|c|c|c|c|c|c|}
\hline \multicolumn{5}{|c|}{2017} & \multicolumn{4}{|c|}{2018} \\
\hline & V1 & V2 & V3 & Mean T & V1 & V2 & V3 & Mean T \\
\hline T1 & 33.470 & 33.567 & 32.967 & 33.334 & 34.433 & 36.183 & 30.373 & 33.663 \\
\hline T2 & 40.300 & 36.317 & 37.690 & 38.102 & 39.587 & 34.900 & 38.000 & 37.496 \\
\hline T3 & 34.450 & 38.033 & 36.533 & 36.339 & 40.710 & 34.000 & 39.020 & 37.910 \\
\hline T4 & 31.583 & 29.373 & 33.550 & 31.502 & 31.180 & 35.730 & 32.047 & 32.986 \\
\hline \multirow[t]{2}{*}{ Mean V } & 34.951 & 34.323 & 35.185 & & 36.478 & 35.203 & 34.860 & \\
\hline & \multicolumn{2}{|c|}{ TREATMENT } & IETY & TXV & \multicolumn{2}{|c|}{ TREATMENT } & VARIETY & TXV \\
\hline $\operatorname{SEm} \pm$ & 0.8 & & 1.20 & 2.07 & 0.92 & & 0.84 & 1.47 \\
\hline CD (5\%) & 3.0 & & 3.59 & 7.19 & 3.20 & & 2.54 & 5.09 \\
\hline
\end{tabular}

Although Zn supply did not show any significant effect on growth parameters like plant height, number of leaves and panicle length, zinc application was proven to have a significant role in ameliorating negative effects of heat stress and improving grain weight under late sown conditions. This was achieved through possible role of zinc in maintaining chlorophyll content, membrane integrity and activating better antioxidant defence system in wheat under late sown conditions. Among all the treatments soil+foliar $\mathrm{ZnSO}_{4}$ (T3) treatment was found best among all others and variety UP2425 (V1) was found best performing variety.

\section{References}

Abbas, G., Khan, M.Q., Jamil, M., Tahir, M. andHossain, F. 2009.Nutrient uptake, growth and yield of wheat (TritcumaestivumL.) as affected by Zinc application rates.Int. J. Agri. Biol., 11(4):389-396.

Ali, S., Khan, S.U., Gurmani, A.R., Khan, A., Khan, S.M., Farid, A., Khan, I. and Zainab, R. 2016. Agronomic and physiological response of wheat (Triticumaestivum L.) genotypes under terminal heat stress conditions. Int. J.Biosci., 8(5): 1-7.
Braun, H.J., Atlin, G. and Payne, T. 2010.In:Reynolds, CRP. (ed.) Climate change and crop production. CABI, London, UK.

DES, 2014.Area, production and productivity of crops.Agricultural statistics at a glance.Directorate of Economics and Statistics, Department of Agriculture andCooperation, Government of India.pp. 77.

FAOSTAT 2012.http://faostat.fao.org.

Firdous, S., Agarwal,B.K. andChhabra, V. 2018. Zinc-fertilization effects on wheat yield and yield components. J.Pharmacog.Phytochem.,7(2): 34973499.

Hasan, M.A., Ahmed, J.U., Bahadur, M.M.,Haque, M.M. and Sikder, S. 2007. Effect of late planting stress on membrane thermostability, proline content and heat susceptibility index of different wheat cultivars. J. Natn. Sci. Foundation Sri Lanka,35(2):109-117.

Keram, K.S., Sharma, B.L., Kewat, M.L. and Sharma, G.D. 2014.Effect of zinc fertilization on growth, yield and quality of wheat grown under agro-climatic condition of kymore plateau of madhyapradesh, India. The BioScan, 9(4): 1479-1483.

Maurya, B.M., Dekate, J. and Upadhyay, V.B. 
2010.Integratednutrient management in rice-wheat cropping system. JNKVV ResearchJ. 44: 39-43.

Mehandi, S.S., Hasan, B. and Singh, L. 2012.Influence of seed rate, nitrogen and zinc on fodder maize in temperate condition of Western Himalayas.Ind. J. Agron.,57(1): 58-88.

Moghadam, M.J., Sharifabad, H.H., Noormohamadi, G., Motahar, S.Y.S. and Siadat, S.A. 2012.The effect of zinc, boron and copper foliar application, on yield and yield components in wheat (Triticuma estivum). Ann. Biol. Res., 3(8): 38753884.

Shaheen, R., Samim, M.K. and Mahmud, R. 2007.Effect of zinc onyield and zinc uptake by wheat on some soils of Bangladesh.J. Soil Nature. 1(1): 07-14.

Sharkey, T.D. 2005. Effect of moderate heat stress on photosynthesis: importance of thylakoid reactions, rubisco deactivation, reactive oxygen species and thermotolerance provided by isoprene. Plant Cell Environ.,28(3): 269-277.
Sharma, G.D., Thakur, R., Raj, S., Kauraw, D.L. and Kulhare, P.S. 2013.Impact of integrated nutrient management on yield, nutrient uptake, protein content of wheat (Triticum astivum) and soil fertility in a TypicHaplustert.The Bioscan, 8(4): 1159-1164.

Wardlaw, I.F., Blumenthal, C., Larroque, O. and Wrigley, C.W. 2002. Contrastingeffectsof chronic heat stress and heat shock on kernel weight and flour quality inwheat. Funct. Plant Biol., 29(1): 25-34.

White, J.W. and Reynolds, M.P. 2001.A physiological perspective on modelling temperature response in wheat and maize crops .In:White, J.W. (Ed.) Modelling Temperature Response in Wheat and Maize. Proceeding of a Workshop. Cimmyt, El Batan, Mexico. pp. 8-17.

Zeidan, M.S., Mohamed, M.F. and Hamouda, H.A. 2010.Effect of foliar fertilization of $\mathrm{Fe}, \mathrm{Mn}$ and $\mathrm{Zn}$ on wheat yield and quality in low sandy soils fertility. World J. Agric. Sci., 6(6): 696-699.

\section{How to cite this article:}

Dheeraj Chatti and Atul Kumar. 2020. Effect of Zinc Nutrition in Mitigating Late Sowing Induced Heat Stress in Wheat Crop. Int.J.Curr.Microbiol.App.Sci. 9(01): 2415-2421. doi: https://doi.org/10.20546/ijcmas.2020.901.275 